\title{
HOMENAGEM AO PROF. ANTÓNIO RIBEIRO GOMES
}

Conheci o Prof. António Ribeiro Gomes em Junho de 1996, alguns dias antes da sua tomada de posse como novo Director do Instituto Universitário de Desenvolvimento e Promoção Social (IUDPS). Guardo desse primeiro encontro, em que me honrou com o seu convite para integrar o Conselho de Direç̧ão do IUDPS, a imagem de um académico da melhor tradição coimbrã, com ideias muito claras sobre o papel a desempenhar pelo ensino superior universitário. Talvez por isso, aceitou com agrado o convite para colaborar com a Universidade Católica em Viseu, pouco tempo depois da sua aposentação voluntária como Prof. Catedrático da Faculdade de Ciências e Tecnologia da Universidade de Coimbra - onde, para além de Professor e Investigador nas áreas da matemática aplicada, foi Presidente do Conselho do Departamento de Matemática e vários anos Presidente do Conselho Científico - , sendo visível o entusiasmo que o animava de poder colocar toda a sua experiência académica ao serviço do IUDPS, da licenciatura de matemática, que criou e coordenou, e do Centro Regional das Beiras.

Durante os três mandatos em que o Prof. António Ribeiro Gomes foi Director do IUDPS, entre Junho de 1996 e Setembro de 2005 , tive a honra e o privilégio de integrar todas as suas 
direç̧ões. Pude, portanto, acompanhar o empenho que sempre colocou no desenvolvimento da unidade de ensino que dirigia, evidenciando sempre uma capacidade ímpar de liderança, mesmo nos momentos mais difíceis da sua vida pessoal, na incessante busca de soluções para tornear os problemas inerentes a uma instituição universitária do interior do país.

O Prof. António Ribeiro Gomes, para além de ter sempre evidenciado, nos mais ínfimos pormenores, ser portador de uma cultura universitária exigente, plasmada numa prática que considerava indissociáveis a investigação e a produção de conhecimento da sua transmissão, teve sempre como princípios orientadores da sua acção no IUDPS dois objectivos essenciais: criar as condições internas e externas para um crescimento sustentado da unidade de ensino que dirigia, através da criação de cursos graduados e pós-graduados com sinergias entre si; e, em paralelo com este primeiro objectivo, dar total prioridade à formação de um corpo docente próprio, facilitando e incentivando o desenvolvimento das suas carreiras, através da frequência de mestrados e doutoramentos, em Portugal e no estrangeiro.

Os últimos anos dos seus mandatos coincidiram com um período particularmente desfavorável à expansão das unidades de ensino universitário, registando-se uma clara retracção deste objectivo, muito por via da diminuição de alunos, mas a estratégia seguida pelo Prof. Ribeiro Gomes de incentivo à formação de um corpo docente próprio acabou por dar os seus frutos, se tivermos em consideração o número de doutorados actualmente integrados no Departamento de Economia, Gestão e Ciências Sociais.

O Prof. António Ribeiro Gomes foi também, durante os nove anos que dirigiu o IUDPS, director da revista Gestão $e$ Desenvolvimento. Muito embora nunca tivesse feito questão de acompanhar em pormenor a elaboração de cada número, cabendo esse papel ao coordenador da revista por si nomeado, cabia-lhe sempre a última palavra sobre o seu conteúdo e, mais importante, nunca deixou de incentivar a sua publicação. Assim, pela ligação intrínseca que a revista sempre teve ao IUDPS e por tudo o que esta unidade de ensino deve ao Prof. Ribeiro Gomes, 
a actual direç̧ão da revista não podia deixar de, com este número duplo, prestar esta singela homenagem ao seu antigo director, um académico de excelência que ficará para sempre, pelo seu exemplo, ligado ao Centro Regional das Beiras da Universidade Católica Portuguesa.

António Rafael Amaro*

* Director da Revista Gestão e Desenvolvimento e do Departamento de Economia, Gestão e Ciências Sociais do Centro Regional das Beiras da Universidade Católica Portuguesa 